\title{
PENGARUH PENAMBAHAN KAOLIN DAN KARBON AKTIF TERHADAP KEKERASAN PADA TEKO TEH POCI
}

\author{
Hansel Muhammad Falah, Agus Setyo Budi, Widyaningrum Indrasari \\ Prodi Fisika, FMIPA, Universitas Negeri Jakarta, Jl. Rawamangun Muka No. 1 RT 11 Rw 14, Pulo Gadung, \\ Kota Jakarta Timur 13220, Indonesia \\ Email: hansel.mfalah@gmail.com
}

\begin{abstract}
Abstrak
Salah satu pekerjaan yang juga banyak digeluti masyarkat Purbalingga yaitu menjadi pengrajin teko teh poci (berbahan dasar tanah liat). Namun, saat ini para pengrajin mengeluhkan masuknya teko teh poci dari mancanegara, yang dapat mengancam industri lokal. Dengan kualitas yang sama namun harga yang lebih murah, membuat teko teh poci buatan lokal sulit untuk bersaing. Maka dari itulah, penelitian ini dilakukan dengan tujuan membuat bahan baku dari teko teh poci (keramik) dengan kualitas lebih baik. Dilakukan analisis terhadap pengaruh penambahan kaolin dan karbon aktif terhadap kekerasan keramik. Hasilnya menunjukan bahwa penambahan kaolin dan karbon aktif meningkatkan nilai kekerasan keramik. Suhu juga sangat mempengaruhi kekerasan, oleh sebab itu diperlukan suhu yang tepat untuk membuat keramik semakin keras, tetapi tidak mengalami vitrifikasi sehingga volume dari keramik tersebut tidak menyusut.
\end{abstract}

Kata kunci: Teko teh poci, tanah liat, keramik, kaolin, karbon aktif, kekerasan, porositas, Purbalingga, lokal.

\section{PENDAHULUAN}

Teh poci, merupakan minuman favorit bagi sebagian besar masyarakat Indonesia, khususnya masyarakat Jawa Tengah dan sekitarnya. Banyaknya penggemar dari teh poci ini, dimanfaatkan sebagian masyarakat sebagai sumber penghidupan atau mata pencaharian di daerah Jawa Tengah, khususnya Purbalingga. Salah satunya dengan membuat dan menjual poci teh. Selain karna banyaknya penggemar dari dari teh poci ini, sumber daya alam yang melimpah juga menjadi alasan utama sebagian masyarakat menjadi pengrajin gerabah. Namun, saat ini para pengrajin mengeluhkan masuknya poci teh tanah liat dari Vietnam, yang dapat mengancam industri lokal. Untuk meningkatkan daya saing dari teko teh poci ini, diperlukan peningkatan kualitas dari teko teh poci itu sendiri. Salah satu peningkatannya yaitu tingkat kekerasan.

Tanah liat adalah campuran partikel-partikel pasir dan debu dengan bagian- bagian tanah liat yang mempunyai sifat-sifat karakteristik yang berlainan dalam ukuran yang kira-kira sama. Salah satu ciri partikel tanah liat yaitu mempunyai muatan ion positif yang dapat dipertukarkan. Material tanah liat mempunyai daya serap yang baik terhadap perubahan kadar kelembapan karena tanah liat mempunyai luas permukaan yang sangat besar ${ }^{[1]}$.Tanah liat atau lempung juga dapat didefinisikan sebagai deposit yang mempunyai ukuran partikel yang lebih kecil atau sama dengan 0,002 mm. 
Tanah liat dengan ukuran mikrokonis sampai dengan submikrokonis ini terbentuk dari pelapukan unsur-unsur kimiawi penyusun batuan ${ }^{[2]}$.

Keramik merupakan bahan material yang banyak dimanfaatkan masyarakat Indonesia sebagai produk kerajinan dan sebagai bahan material bangunan. Produk dari kerajian keramik dapat berupa porselen, ubin, kendi, patung, atau kerajinan yang tidak banyak menerima beban kerja secara terus menerus. Keramik merupakan bahan komposit yang memiliki tahanan suhu tinggi, keausan dan korosi yang lebih baik daripada super alloy namun memiliki sifat getas ${ }^{[3]}$.

Kaolin merupakan suatu mineral lempung berwarna puth yang memiliki komposisi terbesar berupa kaolinit (Al2O3.2SiO2.2H2O). Secara teori mempunyai komposisi 46.3\% $\mathrm{SiO} 2,39.8 \%$ A12O3 and 13.9\% H2O.Kaolin biasa mengandung mineral pengotor seperti quartz, illite, smectite, feldspars dan oksida besi serta hidroksidanya ${ }^{[4]}$. Partikel kaolin biasanya berupa lembaran heksagonal dengan diameter sekitar 0.05-10 $\mu \mathrm{m}$ (rata-rata $0.5 \mu \mathrm{m}$ ). Mineral kaolin dapat terjadi melalui proses pelapukan dan proses hidrotermal alterasi pada batuan beku felspartik dan mika. Kaolin biasanya berada sebagai mineral kaolinit murni, atau mineral yang berhubungan misalnya, haloisit, nakrit, dan dikrit yang bergabung dengan mineral lain seperti smektit, mika, kuarsa, dan feldspar sebagai pengotor ${ }^{[5]}$.

Struktur kristal kaolin terdiri dari pasangan lapisan lembaran silika tetrahedral dan lembaran alumina oktahedral. Masing-masing pasangan dari lembaran tersebut bergabung melalui atom oksigen secara selang-seling, menjadi satu kesatuan melalui ikatan hidrogen antara oksigen dari silika dan oksigen hidroksil dari alumina dengan ketebalan tiap lapisan sekitar $0.72 \mathrm{~nm}$. Ikatan hidrogen tersebut cukup kuat sehingga kaolin tidak mengembang ketika terhidrasi dan kaolin hanya mempunyai luas permukaan luar ${ }^{[6]}$. Kaolin merupakan salah satu mineral lempung dengan nilai Kapasitas Tukar Kation (KTK) yang relatif rendah (3-15 mek/100g) serta luas permukaan spesifik yang relatif kecil, yaitu tidak lebih dari $20 \mathrm{~m} 2 / \mathrm{g}^{[7]}$.

Arang (karbon aktif) adalah bahan padat yang berpori dan merupakan hasil pembakaran dari bahan yang mengandung unsur karbon. Sebagian besar dari pori-porinya masih tertutup dengan hidrokarbon dan senyawa organik lainnya ${ }^{[8]}$. Secara umum ciri-ciri arang yang baik adalah berwarna hitam, tidak mengandung kotoran, bila dipatahkan maka bekas patahannya akan mengkilat, bila dijatuhkan pada benda keras akan berdering, dan bila dibakar tidak cepat habis serta menyemburkan api berwarna biru ${ }^{[9]}$.

\section{METODOLOGI}

Metode yang digunakan yaitu studi literatur terhadap jurnal-jurnal terkait, sebagai bahan dasar pertimbangan dan analisis dari pengaruh penambahan kaolin dan karbon aktif terhadap kekerasan keramik sebagai bahan dasar teko teh poci.

Penelitian pertama yaitu penelitian oleh Setiawan dkk, yang menganalisa kuat tekan campuran tanah liat kaolin dan kuarsa sebagai keramik. Pada penelitian ini, sampel (pasir kuarsa dan lempung) disiapkan dengan cara ditumbuk, sehingga diperoleh material berupa serbuk. Penentuan komposisi bahan dihitung berdasarkan persentase massa. Sampel keramik dibuat dengan komposisi berbeda sebanyak 6 sampel, dengan variasi perbandingan kaolin dan pasir kuarsa 8:0, 7:1, 6:2, 5:3, 4:4 ,3:5. Pembentukan sampel dengan cara cetak dan proses sintering menggunakan furnace hingga mencapai suhu $750^{\circ} \mathrm{C}$ dengan waktu penahanan 1,5 jam.

Kemudian penelitian selanjutnya oleh Siagian dkk, yang membuat keramik berpori berbasis claykaolin dengan aditif abu sekam padi (karbon aktif), dengan komposisi abu sekam padi sebesar 0\%, $5 \%, 10 \%$, dan $15 \%$. Masing-masing sample disinterring pada suhu $900^{\circ} \mathrm{C}, 1000{ }^{\circ} \mathrm{C}, 1100{ }^{\circ} \mathrm{C}$. Karakterisasi yang akan dibahas yaitu uji porositas, densitas, dan kekerasan.

Penelitian berikutnya yaitu penelitian oleh Abdullah dkk, yang mensintesa keramik berbasis komposit clay-karbon dan mengkarakterisasi kekuatan mekaniknya. Karbon aktif yang digunakan dalam bentuk bubuk. Terbuat dari tempurung kelapa yang dihasilkan melalui tahap pengeringan, pembakaran sampai warnanya berubah menjadi hitam sempurna, dan penggerusan dengan mortar hingga halus. Clay dan bubuk karbon dicampur dengan berbagai perbandingan massa, yang kemudian dicampurkan juga dengan air dengan tujuan mendapatkan hasil pencampuran yang homogen. Hasil campuran yang homogen kemudian dikeringkan untuk mengurangi kandungan air 
yang diikuti dengan proses pencetakan dalam cetakan berbentuk silinder dengan diameter $2 \mathrm{~cm}$ dan ketebalan $1 \mathrm{~cm}$. Selanjutnya pembakaran dilakukan dalam furnace yang diprogram pada suhu pemanasan yang naik secara linier selama satu jam ke suhu yang diinginkan kemudian dipertahankan pada suhu tersebut pada berbagai rentang waktu, dan diakhiri dengan pendinginan secara alamiah. Karakterisasi sampel yang dilakukan yaitu uji tekan. Uji tekan dilakukan untuk mengetahui kekuatan keramik yang dibuat pada berbagai perbandingan massa clay/karbon dan berbagai suhu pemanasan.

\section{HASIL DAN PEMBAHASAN}

\section{Pengaruh Penambahan Kaolin}

Berdasarkan penelitian yang dilakukan oleh Setiawan dkk, penambahan kaolin mempengaruhi kenaikan nilai kekerasan pada keramik. Kekerasan sendiri merupakan sifat ketahanan bahan terhadap deformasi plastis karena pembebanan setempat pada permukaan berupa penekanan atau goresan ${ }^{[10]}$. Pada penelitian ini, nilai kekerasan keramik semakin meningkat seiring bertambahnya komposisi kaolin dan berkurangnya komposisi pasir kuarsa. Artinya, bahwa kekerasan berbanding terbalik terhadap penambahan pasir kuarsa, sedangkan berbanding lurus dengan penambahan kaolin pada tiap sampel keramik. Nilai kekerasan yang didapat berkisar pada $286,76 \mathrm{kgf} / \mathrm{cm}^{2}$ hingga $525,54 \mathrm{kgf} / \mathrm{cm}^{2}$. Nilai kekerasan optimum yang dicapai $\left(525,54 \mathrm{kgf} / \mathrm{cm}^{2}\right)$ pada sampel keramik dengan komposisi perbandingan massa kaolin dan pasir silika 8 : 0, dengan massa kaolin 32 gram dan silika 0 gram. Nilai kekerasan yang diperoleh cukup baik, dikarenakan keramik dicetak dengan beban penekanan yang tinggi. Dengan beban penekanan yang tinggi, dapat diperoleh kekerasan Vickers tertinggi $914,340 \pm 92,06 \mathrm{MPa}^{[11]}$. Nilai kekerasan keramik berbanding lurus dengan bertambahnya kaolin. Hal ini disebabkan adanya perbedaan titik lebur antara kaolin dan pasir kwarsa, dimana titik lebur kaolin lebih rendah dibanding titik lebur pasir kwarsa sehingga butiran material kaolin menyusut lebih cepat saat sampel dibakar, dan butiran pasir kwarsa mengisi kekosongan pada keramik ${ }^{[12]}$. Hal ini berpengaruh pada mudahnya keramik mengalami keretakan dan rapuh karena penambahan kadar pasir kuarsa yang terlalu banyak.

Untuk porositas hasil yang diperoleh menunjukkan bahwa semakin banyak penambahan pasir kuarsa, nilai porositas keramik cenderung semakin tinggi. Porositas merupakan banyaknya ruang kosong antar bulir pada struktur mikro material ${ }^{[13]}$. Hasil pengukuran porositas keramik dalam penelitian ini berkisar antara $23,51 \%$ hingga $35,80 \%$. Hasil ini sedikit lebih besar daripada porositas keramik yang ada di pasaran yaitu antara $20 \%-30 \%^{[14]}$. Untuk nilai porositas diperlihatkan bahwa setiap penambahan $5 \%$ pasir kuarsa maka porositas bertambah, artinya bahwa penambahan pasir kuarsa berbanding lurus dengan naiknya porositas. Fungsi awal pasir kuarsa dalam hal ini adalah bahan aditif sebagai penguat ternyata sebaliknya sehingga mempengaruhi nilai porositas keramik. Hal ini dikarenakan selama proses sintering pori-pori dalam keramik terisi oleh butiran-butiran pasir kuarsa yang banyak mengandung silika karena ukuran butir silika relatif lebih kecil dari 33 butiran lempung. Besar kecilnya nilai porositas juga dipengaruhi pada proses pencetakan. Maka, penambahan kaolin berbanding terbalik dengan nilai porositas.

\section{Pengaruh Penambahan Karbon Aktif}

Menurut penelitian oleh Siagian dkk, kenaikan suhu sintering akan menurunkan porositas yang disertai dengan kenaikan nilai densitas karena butiran-butirannya akan semakin rapat sehingga akan mengurangi celah/pori. Sampel dengan persentase komposisi abu sekam padi yang sama, semakin tinggi suhu sintering maka porositas semakin kecil. Sedangkan untuk suhu sintering yang sama, semakin banyak penambahan komposisi abu sekam padi maka nilai porositas semakin besar. Pada uji kekerasan, hasil uji menunjukkan kecenderungan perubahan nilai kekerasan yang semakin meningkat terhadap penambahan komposisi zat aditif dan peningkatan suhu sintering. Dengan meningkatnya suhu sintering rapat massa yang didapat semakin tinggi, hal ini disebabkan karena terjadinya pemadatan diantara partikel-partikel sehingga ikatan yang terbentuk semakin kuat dan kekerasannya akan semakin meningkat. Nilai kekerasan maksimum diperoleh pada suhu $1100^{\circ} \mathrm{C}$ 
sebesar $12,87 \mathrm{kgf} / \mathrm{mm}^{2}$ pada aditif $15 \%$. Sedangkan nilai minimum diperoleh pada suhu $900^{\circ} \mathrm{C}$ sebesar $8,78 \mathrm{kgf} / \mathrm{mm}^{2}$ dengan aditif $0 \%$.

Kenaikan nilai kekerasan akibat penambahan karbon aktif juga diperkuat oleh penelitian dari Abdullah dkk, yang menyebutkan bahwa kekuatan mekanik (kekerasan) keramik yang dicampur dengan karbon aktif, delapan kali lebih keras dibanding keramik biasa. Namun, nilai ini berlaku hanya pada penambahan tertentu dan pembakaran dalam waktu tertantu. Penambahan di atas nilai $0,05-0,1 \mathrm{w} / \mathrm{w}$, akan kembali menurunkan nilai kekerasan dari keramik itu sendiri. Hal ini disebabkan penambahan karbon aktif yang belebih, berakibat pada munculnya ikatan baru, yaitu ikatan antar karbon yang sifatnya lebih lemah dibandingkan ikatan antar clay dan ikatan antar claykarbon. Pembakaran dalam rentang waktu yang lebih panjang dari 2 jam juga menurunkan kekuatan keramik, yang diduga akibat hilangnya karbon (penguapan) akibat pembakaran yang lama.

\section{SIMPULAN}

Hasil dari pembahasan mengenai pengaruh penambahan kaolin dan karbon aktif terhadap kekerasan keramik sebagai bahan baku teko teh poci yaitu kaolin dapat meningkatkan kekerasan pada keramik, dimana penambahan kaolin berbanding lurus dengan kanaikan nilai kekerasan pada keramik. Penambahan kaolin juga menurunkan nilai porositas dari keramik, dimana penambahan jumlah kaolin berbanding lurus dengan penurunan porositas dari keramik tersebut. Penambahan karbon aktif juga dapat meningkatkan kekerasan dan porositas dari keramik. Tetapi, penambahan karbon aktif yang terlalu berlebih dapat mengakibatkan munculnya ikatan baru pada keramik, yaitu ikatan antar karbon yang sifatnya lebih lemah dibandingkan ikatan antar clay dan ikatan antar claykarbon. Kemudian perlu diperhatikan juga suhu sintering serta lama pembakaran, karena suhu sintering yang terlalu rendah dapat menyebabkan porositas yang tinggi serta densitas yang rendah. Sementara, waktu pembakaran yang terlalu lama dapat menurunkan kekuatan keramik, akibat hilangnya karbon (penguapan) ketika pembakaran terlalu lama.

\section{REFERENSI}

[1] U. N. Mahida, "Pencemaran air dan Pemanfaatan Limbah Industri," Kata Pengantar Otto Soemarwoto, Jakarta: CV. Radjawali, 1984.

[2] J. Bowles, "Sifat-Sifat Fisis dan Geoteknis Tanah (Mekanika Tanah)," Jakarta, Edisi Kedua: Erlangga, 1991.

[3] H. Subiyanto \& Subowo, "Pengaruh Temperatur Sintering Terhadap Sifat Mekanik Keramik Insulator Listrik," Jurnal Teknik Mesin, 2003.

[4] S. O. Lee et al., "Dissolution of iron oxide using oxalic acid. J.Hydrometallurgy," 2007.

[5] H. H. Murray, "Structural variations in some kaolinites in relation to dehydrated halloysite," American Mineralogist, vol. 39, pp. 97-108, 2004.

[6] Sunardi, U. Irawati, T. Wianto, "Karakterisasi Kaolin Lokal Kalimantan Selatan Hasil Kalsinasi,”Jurnal Fisika FLUX, vol. 8, pp. 59-65, 2011.

[7] J. Konta, "Clay and man: Clay raw materials in the service of man. Applied Clay Science," vol. 10, pp. 275-335, 1995.

[8] P. M. Naibaho, M. Adelina, "Studi Efisiensi Pengolahan dan Produktivitas Pabrik Kelapa Sawit," Berita PPKS, Medan, vol. 2, 1994.

[9] Departemen Perindustrian dan Perdagangan, "Syarat Mutu dan Uji Arang Aktif SII No. 0258-88," Palembang: Balai Perindustrian dan Perdagangan, 2003.

[10] S. Kirono \& A. Amri, "PENGARUH TEMPERING PADA BAJA St 37 YANG MENGALAMI KARBURASI DENGAN BAHAN PADAT TERHADAP SIFAT MEKANIS DAN STRUKTUR MIKRO," Jurusan Mesin, Universitas Muhammadiyah Jakarta, pp. 1-10, 2013. 
[11] M. Amin \& B. Irawan, "Pengaruh Tekanan Kompaksi Dan Suhu Sintering Terhadap Densitas Keramik Lumpur Lapindo," Prosiding Seminar Nasional Unimus, pp. 290-295, 2010.

[12] A. P. Bayuseno, "Pengembangan Dan Karakterisasi Material Keramik Untuk Dinding Bata Tahan Api Tungku Hoffman K1, vol. 11, no. 4, pp. 5-10, 2009.

[13] E. P. Sari, A. S. Budi \& E. Budi, "Seminar Nasional Fisika 2012 ZEOLIT DAN TANAH LEMPUNG Seminar Nasional Fisika, pp. 67-71, 2012.

[14] D. M. Effendi, "ANALISA KIMIA DAN IDENTIFIKASI MUTU KAOLIN BANGKA BERDASARKAN SYARAT MUTU KAOLIN SEBAGAI BAHAN BAKU KERAMIK HALUS (SII.0654-82)," Badan Pengkajian dan Penerapan Teknologi Unit Pelaksana Teknis Pengembangan Seni dan Teknologi Keramik dan Porselin, Bali: Deputi Bidang Teknologi Informasi, Energi, Material dan Lingkungan, 2004.

[15] F. Setiawan et al., "Analisis Porositas dan Kuat Tekan Campuran Tanah Liat Kaolin dan Kuarsa sebagai Keramik," Jurnal MIPA, vol. 40, no. 1, pp. 24-27, 2017.

[16] H. Siagian \& M. Hutabalian, "Studi pembuatan keramik berpori berbasis clay dan kaolin alam dengan aditif abu sekam padi," Jurnal Saintika, vol. 12, no. 1, pp. 14-23, 2012.

[17] M. Abdullah et al., "Sintesis Keramik Berbasis Komposit Clay-Karbon dan Karakterisasi Kekuatan Mekaniknya," vol. 2, no. 2, 2009. 
